\title{
The Impact of Involving Students in Managing the Quality of Higher Education Provision
}

\author{
Evelyn Chiyevo Garwe \\ Correspondence: Evelyn Chiyevo Garwe, Deputy Chief Executive Officer for the Zimbabwe Council for Higher \\ Education, Zimbabwe
}

Received: January 19, 2015 Accepted: February 3, 2015 Online Published: February 10, 2015

doi:10.11114/jets.v3i2.672

URL: http://dx.doi.org/10.11114/jets.v3i2.672

\begin{abstract}
This study was aimed at exploring the power of student involvement in improving quality of higher educational provision in private higher education instititions in Zimbabwe. A longitudinal approach involving two separate surveys and covering a period of three years was used. A preliminary survey aimed at assessing the issues that impact negatively on teaching and learning in five private universities was made from June 2011 to May 2012. In 2013, a follow-up survey was carried out to check whether the pertinent issues raised by students had been addressed promptly and adequately. Data collection included semi-structured self-administered questionnaires as well as focus group discussions with students and academic staff. The sample represented ten per cent of the enrolments of students at each university. The sample was representative of gender, study discipline and level of study. The issues that were prioritised as adversely affecting quality of teaching and learning were limited reading material; poorly qualified Lecturers; sub-standard teaching venues; inadequate assignments; part-time lecturers who abscond; sexual harassment and inadequate field trips and practical work. During the second survey, results showed that students were satisfied by the fact that all five higher education institutions had addressed most of the students' concerns. However, continued increase in student enrolments perpetuated the problem of poor teaching venues. Part time lecturers continued to contribute negatively to the quality of teaching and learning. The study points to the need to continuously involve students as an effective way of improving quality of educational provision.
\end{abstract}

Keywords: student involvement, quality improvement, teaching and learning, private universities

\section{Introduction}

Private universities in Zimbabwe recognise that in order to be competitive, attract, satisfy, develop and retain students, they need to continuously pay attention to improving the quality of educational provision. This will assist in producing graduates who will subsequently become successful and productive citizens. This quest is exemplified by the motto of one of the six private universities, the Women's University in Africa in its Strategic Plan for 2012-2015, 'Growth with Quality.'

The benefits of involving students in managing quality of educational delivery and improving student satisfaction and retention are well recognised (Evans, Forney, \& Guido-DiBrito, 1998; Bahou, 2011; Bragg \& Manchester, 2012; Leach, 2012; Rodrigues, 2013). Student involvement affords them the opportunity to actively articulate their views and to be partners in the planning, implementation and appraisal of their teaching and learning experience (QAA, 2012) with the aim of improving quality (Rogers, 2005). Student involvement has been encouraged by governments, non-governmental organisations, university management, academic staff and student bodies (Carey, 2013). This position derives from the favourable outcomes accruing to students and institutions including: intellectual gains, satisfaction, social engagement and retention (Berger \& Milem, 1999; Kuh \& Hu, 2001; Kuh, Kinzie, Buckley, Bridges \& Hayek, 2007; Kuh, Cruce, Shoup,Kinzie \& Gonyea, 2008).

Student involvement in this study is understood in the context of the definition given by Trowler (2010) who avers that "Student involvement is concerned with the interaction between the time, effort and other relevant resources invested by both students and their institutions intended to optimise the student experience and enhance the learning outcomes and development of students and the performance, and reputation of the institution." Although the author is cognisant of the fact that some researchers make a distinction between student involvement and engagement, this study remains focused on student involvement. These researchers posit that engagement involves feelings, sense-making and activity and is thus 
is much more than involvement or participation (Fredricks, Blumenfeld \& Paris, 2004; Harper \& Quaye, 2009). They further argue that involvement could mean acting without feeling engaged (compliance) or feeling engaged without acting (dissociation).

According to Jackson (2006), students are pivotal to the higher education system in that they contribute time, money, energy and intellect. Bloxham \& Boyd (2007) and Rudduck (2007) posit that since students play a critical role in the judgement process and in the advancement of knowledge, it would be insensitive to view them as merely recipients of wisdom. By interrogating students on quality of their learning experiences, Blair \& Noel (2014) found that students were able to point out areas needing improvement and to suggest ways to rectify the problems. Levin (2000) avers that students are best placed to utilise their experiences in identifying what motivates them and proffer their opinions on the quality of social services and university resource provision. They can also pass judgement on the content of the curriculum, length of studies as well as teaching and learning methods.

Student involvement is very useful for higher education institutions as reported by Coates (2010) who found that through student involvement institutions can easily identify areas of good practice as well as those areas in need of improvement. Indeed, many institutions urge students to offer regular feedback regarding all their experiences during the study period. Reid (2010) found that students are kept motivated when they are involved, participate and contribute in activities that enhance the quality of their education. This enhances the students' total learning experience (QAA, 2012). In order to achieve this, the university should create a culture and a conducive environment which has transparent formal and informal mechanisms of engaging students in their quality processes.

The current mechanisms used by institutions to involve students include surveys, evaluations and special project focus groups as well as student representation at all levels, student approaches to learning, and learning development (Hodkinson \& Shaw, 2013). These mechanisms make use of questionnaires and other data gathering instruments to collect feedback, utilising student representatives to sit on various university-wide Committees, carrying out student consultative events, involving students in university projects, encouraging students to participate in discussion forums available online and carrying out quality assurance processes, including course and programme reviews (QAA, 2012). Some higher education institutions train students and empower them to get their voices heard more effectively (McKeachie \& Svinicke, 2006).

Zimbabwe's public higher education institutions once faced a serious problem of students' unrest, demonstrations and clashes with law enforcement agents. On the other hand, private institutions enjoyed a calm environment. This scenario is not unique to Zimbabwe, as many researchers found that private higher education institutions possess favourable attributes including: involvement of students, learner-friendliness, cultural diversity, less prone to political interference or activism, secular (Levy, 2007), improving access (Oketch, 2009; Chae \& Hong, 2009; McCowan, 2004), more responsive to national economic priorities (Jalowiecki 2001) and accommodative to societal higher education needs (Galbraith (2003). This study was therefore focused at private universities with the assumption that these institutions involve their students effectively. No study in Zimbabwe has been documented whether private universities effectively involve students and if they do how this impacts on the quality of higher education delivery. This created a gap that this study intended to address.

\section{Objectives of the Study}

The objectives of this study were to first and foremost establish those challenges faced by students which they perceive to have detrimental effects on the academic well-being of either individual students or the student body as whole. Secondly, the study aimed to ascertain whether the private higher education institutions involve students and listen to their concerns by implementing corrective measures using the feedback and inputs given. The study is unique in that it focuses on investigating the benefits of student involvement from the vantage point of the 'student voice' and not what is written or said about students by others.

\section{Methodology}

In line with the objectives of the study and according to recommendations by Wilson, Lizzio \& Ramsden (1997) and Oppermann, (1997) for such studies, a two-phase longitudinal study which targeted the private universities in Zimbabwe was carried out from 2011 to 2013. Data collection mainly focused on questionnaires and focus group discussions although observation and document analysis was also used. The questionnaires were meant for students only and were designed to allow them to supply information regarding their total campus experience (positive and negative) and to suggest ways of tackling areas requiring improvement. Focus group discussions were necessary so as to confirm, contextualise and further pursue the issues identified from the questionnaires. Students and staff members who contributed to the focus group discussions were randomly picked from their respective faculties. However, although the main target of the study was the student body, it was necessary to verify and seek explanations from academic and administrative staff on issues raised by the students. Hence, focus group discussions were first undertaken with students, and later with staff. 
The target population comprised of six private universities in Zimbabwe namely: Women's University in Africa (WUA), Africa University (AU), Solusi University (SU), Catholic University in Zimbabwe (CUZ), Zimbabwe Ezekiel Guti University (ZEGU) and the Reformed Church University (RCU). However, RCU was left out because at the commencement of the study all its students were off campus since they were all using the block release model. The sample represented ten per cent of the enrolment of each university. The researcher first analysed the secondary data on students' enrolment using institutional databases available at the Zimbabwe Council for Higher Education (ZIMCHE). This analysis was for purposes of determining the number of students available as well as categorising them by gender, field of study, level of study (undergraduate and postgraduate) and year of study (year 1 to 5 depending on programme duration). The researcher then randomly selected a sample stratified for each of these categories to represent ten per cent of the students at each university. The total student population for the 5 private universities under study during the first phase of the study was 6581 and hence a total of 670 questionnaires were distributed. However, a total of 651 questionnaires were satisfactorily completed with response rates differing from university to university.

Although the study was performed by ZIMCHE officials as part of their mandate to promote institutional quality, the design, analysis and documentation was carried out by the researcher who is an employee of ZIMCHE. The results were made known to all the higher education institutions involved and they made their input and comments before publication of the results. The research team from ZIMCHE first communicated with the university management prior to the commencement of the study. Questionnaires were then distributed to Deans of students and given to the randomly selected students according to the set categories. The questionnaires were collected and send to ZIMCHE. The research team then visited each university and carried out focus group discussions first with students from all categories and then with staff members to cross validate issues raised by students.

The issues of concern or the good practices raised by students from each university were communicated to the lecturers and the university administration by the researchers. This was done in order to inform them of issues that students might find difficult to point out in the presence of their superiors.

In 2013, a follow-up study targeting the same five private universities was done to check whether the issues of concern raised by students had been addressed. The procedure was basically the same with that of the first phase. However, the student population had risen to 8186 therefore in line with the 10 per cent sample, 820 questionnaires were distributed and 560 were satisfactorily completed. The researchers then carried out focus group discussions with students and subsequently with staff.

\section{Results and discussion}

The results for the first phase of the study are presented first before those from the follow-up survey are presented.

\subsection{Findings from the First Phase (2011-2012)}

\subsubsection{Socio-Economic and Demographic Characteristics of Students}

From the sample of sample of 670 students from the five private universities, 651 successfully completed questionnaires. The survey included students from all study disciplines in private universities namely agriculture, commerce, health studies, education, religious studies and social sciences. Table 1 shows the proportion of students that were involved in the first survey from each university.

Table 1. Percentage distribution of universities from which students were sampled

\begin{tabular}{lll}
\hline Institution & Enrolment (2011) & Sample (\%) \\
\hline Women's University in Africa & 1970 & 6.3 \\
Africa University & 2100 & 8.3 \\
Solusi University & 2089 & 8.2 \\
Catholic University in Zimbabwe & 402 & 7.5 \\
Zimbabwe Ezekiel Guti University & 20 & 34 \\
\hline
\end{tabular}

$\mathrm{N}=651$

As shown in Table 1, although questionnaires had been given to ten per cent of students in each university, the students who successfully completed the questionnaires ranged from 6.3 to 34 percent of all the students. However, the total number of successfully completed questionnaires (651) represented 10 per cent of the students in the five private universities. 


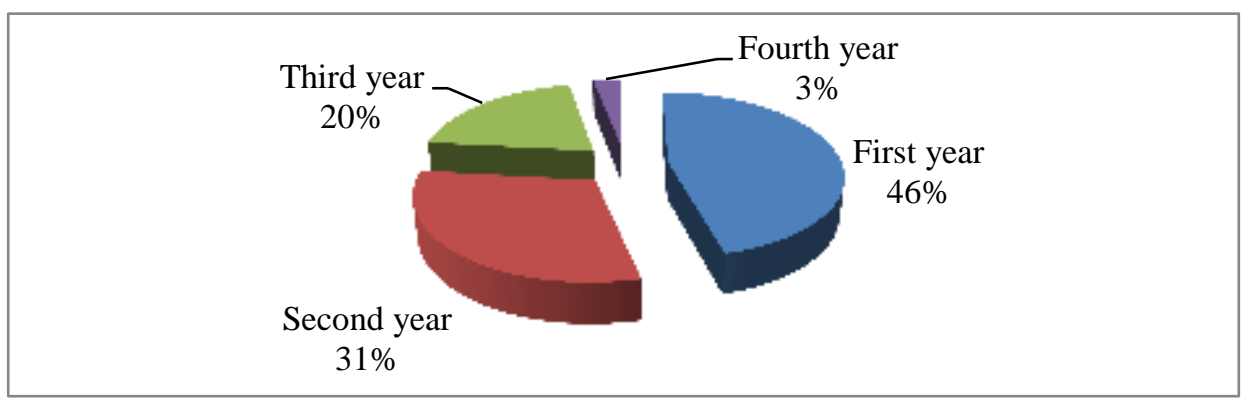

Figure 1. Percentage distribution of year of study for students were sampled

Figure 1 shows that the students who completed questionnaires comprised mostly of first years (46\%). Similar statistics were reflected in the distribution of students who participated in the focus group discussions. A total of 800 students and 75 staff members formed part of the focus group discussions.

\subsubsection{Quality of Teaching}

The rating by students of their perceived quality of teaching and learning is shown in Table 2. The private institutions involved in the study are denoted by letters A to $\mathrm{E}$ in order to address issues of anonymity.

Table 2. Percentage distribution of rating on quality of teaching

\begin{tabular}{llll}
\hline Institution & Excellent (\%) & Good (\%) & Poor (\%) \\
\hline A & 42.6 & 33.6 & 24 \\
B & 44.8 & 51.2 & 4 \\
C & 44 & 37 & 19 \\
D & 8.1 & 44.9 & 47 \\
E & 43 & 34 & 23 \\
Average & $\mathbf{3 6 . 5}$ & $\mathbf{4 0 . 2}$ & $\mathbf{2 3 . 4}$ \\
\hline
\end{tabular}

$\mathrm{N}=651$

Table 2 shows that the average scores for excellent, good and poor quality of teaching ratings were $36.5,40.2$ and 23.4 respectively. The university where the students had the highest excellent rating for quality of teaching was University $\mathrm{C}$ $(44.8 \%)$. The same university also had the highest score for good quality of teaching of $51.2 \%$. University D had the highest rating for poor quality of teaching of $47 \%$.

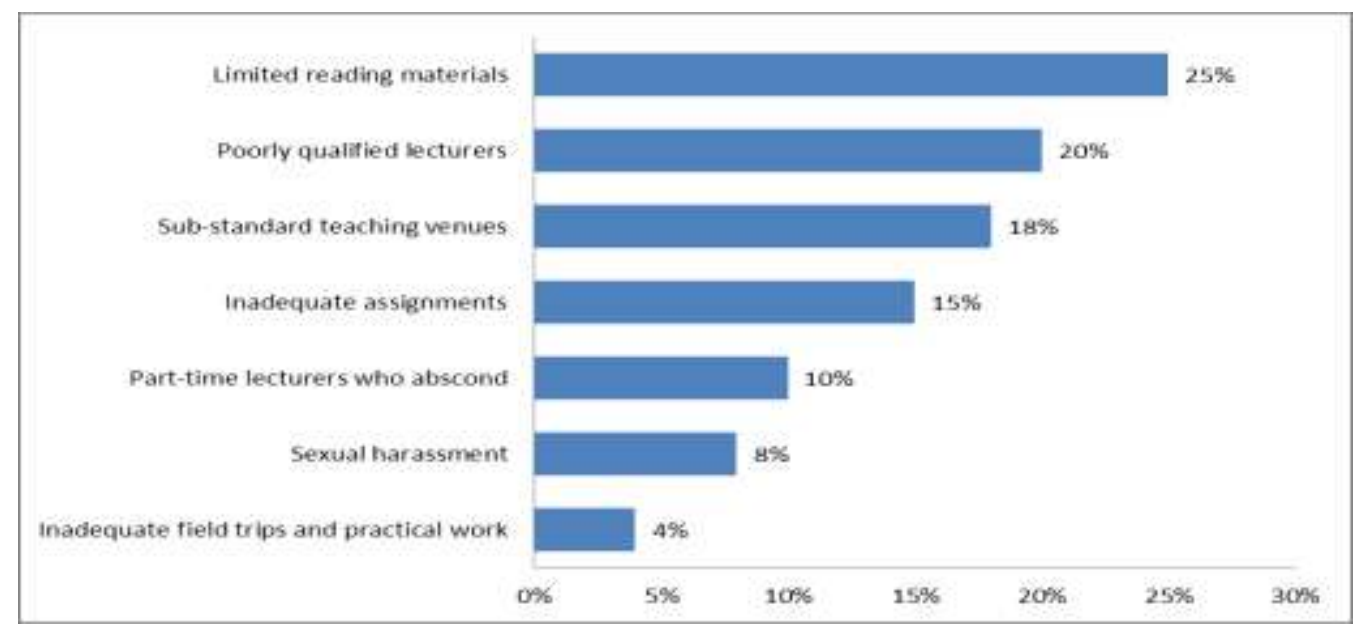

Figure 2. Reasons for poor quality teaching

Figure 2 shows that the reasons for poor quality of teaching included, in order of importance: limited reading material (25\%); poorly qualified Lecturers (20\%); sub-standard teaching venues (18\%); inadequate assignments (15\%); part-time lecturers who abscond (10\%); sexual harassment (8\%) and inadequate field trips and practical work (4\%). 


\subsubsection{Limited Reading Material}

The students who complained about inadequate reading material (25\%) mentioned both library hard copies as well as electronic resources. These students were mostly from three of the five private institutions. Students from one of the universities praised their institution for providing adequate books and electronic resources. In fact during focus group discussions students mentioned that they were able to access electronic books from the library even in their home countries all over Africa.

\subsubsection{Poorly Qualified Lecturers}

The concerns expressed by 20 per cent of the students about lecturers who were not sufficiently qualified were further explored using secondary data on staff qualifications available at ZIMCHE. The academic staff statistics for 2012 (see Figure 3) revealed that the majority of academic staff in the five private universities had Masters' degrees (65\%) as compared to Bachelors (24\%) and Doctorates $(11 \%)$. However, the proportions of academic staff with these three qualification levels differed according to the different universities. Universities with the highest proportion of staff with Doctorates were University C (29\%) and University B (17\%). A study by Mhlanga, Matope, Mugwagwa, Phuthi \& Moyo, (2013) focusing on university teaching staff in engineering departments in Zimbabwe found ratios of 51\%, 34\% and $15 \%$, for Masters, Bachelors and $\mathrm{PhD}$, degree holders respectively. The average ratio of lecturers with Doctorate Degrees $(11 \%)$ fell below the international and regional standards. Nigeria for example had 40 per cent of its lecturers holding Doctorate Degree (Adeyemo, 2012). However, during the focus group discussions, lecturers argued that these ratios resulted from the brain drain challenges experienced by Zimbabwean universities from 2005 to 2009. In addition there were no funds and opportunities available for staff development. All the five private universities were not offering doctorate degrees. The highest qualifications offered were at Masters' degree level.

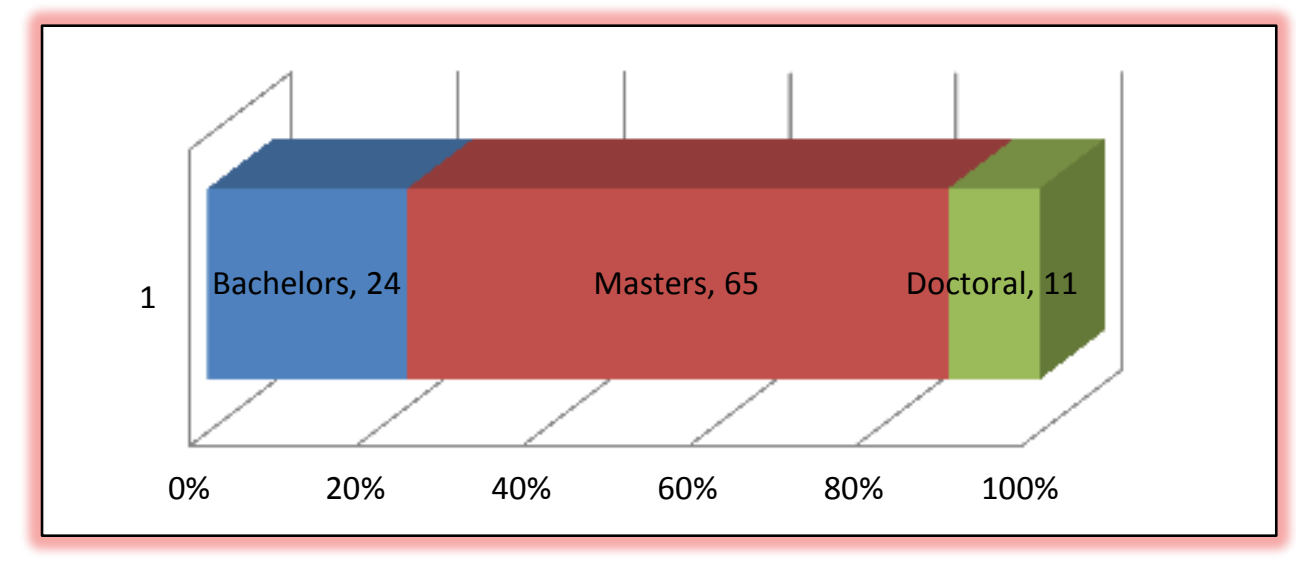

Figure 3. Academic Staff qualifications

\subsubsection{Sub-Standard Teaching Venues}

Eighteen per cent of the students who answered the questionnaires decried the poor state of the classrooms. Some of the classrooms were too small and students were squashed or they were very large and packed with students such that it was virtually impossible to hear what the lecturers were saying. The furniture in the rooms was also sub-standard, at times there were no tables or desks or there was shortage of furniture. In addition, some of the classrooms lacked proper ventilation. The focus group discussions also buttressed the challenges of inappropriate teaching venues. Comments like "It is just that we are committed to our studies otherwise the conditions here are no different or worse than those at high school" and "The classroom conditions exudes the aura of a place were no serious or important business is done" were given by students. Staff members also felt the same as one member said, "Considering that students pay relatively high fees compared to public universities, the state of teaching venues and some staff offices reveal illogical or misplaced priorities in the allocation of resources."

\subsubsection{Inadequate Assignments}

Students complained that some Lecturers especially those employed on a part time basis, gave students just one assignment per course. In addition, the assignments would be marked and returned just before they sit for exam or at times even after the exam. Apart from receiving the feedback on assignments late, some Lecturers just put marks alone without any comments. This unsatisfactory situation of inadequate and infrequent assignments coupled with the poor quantity and quality and timeliness of this feedback caused a serious dent in the quality of learning. Many studies have underscored the importance of formative assessments in that they help students to assess themselves for purposes of 
learning and directing their future studies (Black \& Wiliam's, 1998; Brookhart, 2001; Maclellen (2001); Ramsden, 1992).

\subsubsection{Part-Time Lecturers}

Most private universities in Zimbabwe rely more on part-time lecturers and have relatively less academic staff members who work on full-time basis. Ten per cent of the students blamed poor quality teaching on part-time Lecturers who abscond themselves from lectures. The Lecturers will therefore either fail to complete the syllabus or if they do they will make it a crush programme and it is usually very difficult for the student to understand and internalise the information. Focus group discussions with staff members revealed that students were correct and enlightened the researchers by indicating that part-time academics find it difficult to follow the timetable since they are full-time employees elsewhere. In addition, they do not have time to consult and mentor students outside the lecture times. Part-time Lecturers also tended to be less committed to the institution since they did not participate in university service activities like meetings and taking up some academic and non-academic roles. Indeed Gappa \& Leslie (1993) aver that part-time staff is detached from the "mission and spirit of the institution."

\subsubsection{Sexual Harassment}

Although sexual harassment was mentioned by $8 \%$ of the respondents, all these were coming from only two of the five private universities. During focus group discussions students from that private university flagged this as a major problem. It was so serious that they threatened to provide the names of the staff members concerned. It was also important to note that the perpetrators of sexual harassment were not only lecturing staff, administrative staff members were also alleged to be involved. Female students tended to be more vulnerable to sexual harassment than their male counterparts. Students expressed their lack of confidence in the institutional and legal systems and reporting structures. They highlighted that it was not easy to report sexual harassment cases since they were threatened by their abusers and in addition even if they reported the matter to the police, these would embarrass the victims and demand for concrete evidence. Most victims preferred therefore, to just suffer in silence since there was little hope of getting justice when perpetrators receive adequate punishment. It was clear that students and victims will willingly discuss the issue with people they trust as was the case with the researcher.

Sexual harassment is defined as gender discrimination characterised by unwanted and unsolicited sexual advances, requests for sexual favours and other verbal or physical conduct of sexual nature (Aluede, 2000; Argus 2004). The major reasons given by students as the causal factors for sexual harassment were securing a place at university, awarding of undeserved marks, provision of financial and material support as well as other favours. Students cited that a Lecturer would ask them to collect assignments from his/her office instead of bringing them to class. Some students would even be victimised by being made to repeat courses if they fail to comply with the demands of the sexual advances of the staff member. Students denoted this practice as "a thigh for a mark" or "sexually transmitted marks."

Focus group discussions with staff, whilst confirming that this was indeed a challenge, blamed the suggestive conduct and indecent dressing of female students as the major cause of them being sexually harassed. According to staff members "Some female students blatantly parade parts of their bodies by wearing skimpy clothes thereby exposing themselves to sexual harassment." The views of staff on causes of sexual harassment are similar to the findings by Opong (1995) that the way female students conduct themselves in terms of behaviour and dressing influences their vulnerability to sexual harassment.

\subsubsection{Inadequate Field Trips and Practical Work}

Students studying in the science and related fields complained that they were not adequately exposed to practical work and field trips that could help to enhance their skills. Focus group discussions with staff members endorsed this state of affairs. Whilst agreeing that practical work and field trips were critical in showing and putting students into settings suitable for manipulating objects and materials and discover the outcomes for themselves, the situation was beyond their control. The reasons given for this scenario were shortage of funds, laboratories, equipment, consumables as well as transport. Indeed, Braund \& Reiss (2006) emphasise the importance of field trips and practical work, categorising them into the following three areas:

the actual world (e.g. as accessed by field trips and other visits to see science in use);

the presented world (e.g. in science museums, botanic gardens and zoos); and

the virtual world (e.g. through simulations).

\subsection{Reporting Mechanisms and Instructional Action Plans}

ZIMCHE officials met with each private institution's leadership after the first visit for purposes of debriefing them on the major outcomes of the exercise. They verbally indicated the preliminary findings but followed up by providing 
written reports. The leadership of each institution were given the opportunity to verify and comment on the report after which they were requested to come up with an action plan for implementation. In cases were the students had indicated satisfaction with certain practices, they were requested to document the good practices and forward them to ZIMCHE for onward dissemination to similar institutions. Institutional internal processes and systems were used to take corrective measures on issues and concerns raised by students. After a year (in 2013), ZIMCHE carried out follow-up survey to check on the implementation status and the results thereof regarding the concerns raised by students during the initial survey.

\subsection{Findings from the Second Survey}

\subsubsection{Student Enrolments}

Secondary data from the ZIMCHE database showed that all the six private universities in Zimbabwe had registered an increase in student enrolment compared to 2011 statistics (see Table 4).

Table 4. Change (\%) in student enrolments for 2011 and 2013

\begin{tabular}{llll}
\hline Institution & 2011 Enrolment & 2013 Enrolment & \% Change \\
\hline Women's University in Africa & 1970 & 2751 & 40 \\
Africa University & 2100 & 2504 & 19 \\
Solusi University & 2089 & 2142 & 3 \\
Catholic University in Zimbabwe & 402 & 558 & 39 \\
Zimbabwe Ezekiel Guti University & 20 & 34 & 70 \\
Reformed Church University & 70 & 197 & 181 \\
TOTAL & 6651 & 8186 & 23
\end{tabular}

Table 4 shows that the Reformed Church University registered the most significant change in enrolment (181\%). This increase was due to the fact that the institution was new and hence was still growing. However, RCU had not participated in the first survey and hence it was also not involved in the 2013 survey.

\subsubsection{Factors Affecting the Quality of Teaching and Learning}

The following seven reasons that had been flagged to affect the quality of teaching and learning in the first survey: limited reading material; poorly qualified Lecturers; sub-standard teaching venues; inadequate assignments; part-time Lecturers who abscond; sexual harassment and inadequate field trips and practical work. The follow-up survey showed that significant and positive measures had been put in place by the university management in consultation with students. The quality and quantity of reading material had improved both in print and electronic form. However, the increase in student enrolments resulted in new challenges of teaching space and equipment. Some of the developments are highlighted in the sections that follow.

\subsubsection{Lecturer Qualifications}

Table 5 shows a comparison between the ratio of Doctorate, Masters and Bachelors' Degree holder between the first survey (2011) and the second survey (2013).

Table 5. Proportions of academic staff holding Doctorate, Masters and Bachelors' Degrees

\begin{tabular}{llll}
\hline Qualification & 2011 & 2013 & \% Change \\
Doctorate degree & 11 & 15 & 36.3 \\
\hline Masters' degree & 65 & 75 & 15.3 \\
Bachelors' degree & 24 & 10 & 58.3
\end{tabular}

It is clear from Table 5 that overall, the proportion of academic staff in the universities who are Doctorate Degree holders increased by $25 \%$. This improvement was attributed to recruitment of Zimbabwean Lecturers from the Diaspora as well as staff development of Lecturers who were previously Masters Degrees holders. There was a marked (60\%) decrease in the proportion of academic staff with Bachelor's Degrees.

\subsubsection{Sexual Harassment}

Students from the two private universities that had initially complained about sexual harassment reported a major improvement in this area resulting from interventions by university management. Appropriate disciplinary action had been taken against staff members who had been incriminated. Two of the staff members had been dismissed. The universities had developed reliable reporting systems and sexual harassment policies and procedures. The university 
security personnel had been well equipped and empowered to ensure rapid action. Students, staff and student counselors had been trained on how to prevent and handle cases of sexual harassment effectively. Suggestion boxes and telephone hotlines were made available to all students within and outside the campusenable students to provide information on perpetrators anonymously. Agreed dress codes were being enforced.

\subsubsection{Focus Group Discussions}

Students and staff confirmed the findings from questionnaires that indeed the quality of teaching and learning had improved due to the interventions by management after results of the first survey had been disclosed. Focus group discussions with both students and staff highlighted that students were very happy to be involved in teaching and learning issues. They had greatly valued the exercise performed by ZIMCHE. They clearly stated that although they had previously been engaged through lecturer evaluations and student representatives at various university committees and fora, there were some issues that they had found difficult to disclose for fear of victimisation. The coming in of external people from ZIMCHE and the subsequent willingness of the university management to address their issues was really welcome.

\section{Discussion and Analysis}

The findings of the first survey revealed that limited reading material; poorly qualified Lecturers; sub-standard teaching venues; inadequate assignments; part-time Lecturers who abscond; sexual harassment and inadequate field trips and practical work were the major factors negatively impacting on the quality of teaching. Darling-Hammond (2012) argues that the quality of teaching and learning depends on the lecturer's relevance of qualifications and personality; the curriculum and assessment system; as well as the learning environment inclusive of class size, facilities, and equipment. Therefore if the quality of educational provision is to improve, university leaders ought to pay attention to the aptitude and qualifications of Lecturers as well as the teaching and learning environment. This study is important in that it clearly shows that in addition to these, student involvement is a critical dimension necessary for the improvement of quality. This argument stems from the fact that when the private higher education institutions were notified about the student concerns regarding these issues, they adequately and timeously addressed them to the satisfaction of students thereby increasing student morale and the quality of teaching and learning.

Students greatly valued the process of seeking their views and redressing their issues. Hodkinson \& Shaw (2013) also reported that when students notice that their inputs are respected and when they derive benefit from their contribution, there is increased engagement and improved quality of the learning environment. Students, when engaged by an external body like ZIMCHE, felt free to reveal tough issues that they would normally not highlight to their lecturers and administrators. These included reporting sensitive matters like sexual harassment as well as exposing inherent injustices.

This encourages the students learn with purpose and they can individually and collectively improve their learning environment and academic performance through relevancy and relationships. Although the study showed that other challenges can resurface after the others had been solved, students felt that they can remain relevant through continuously having their voice sought for and heeded.

\section{Conclusion}

The study concludes that indeed private higher education institutions in Zimbabwe were involving students and heeding the student voice as a way of enhancing the quality of educational provision. The relevance of external quality assurance bodies in the process was highlighted by the fact that there were some sensitive issues for example issues of sexual harassment that students are not at liberty to reveal to internal staff members. However, they are open and free to discuss such issues with officials from external quality assurance bodies like ZIMCHE.

\section{Acknowledgements}

The researcher acknowledges support from ZIMCHE and the Ministry of Higher and Tertiary Education, Science and Technology Development as well as co-operation from the five private universities involved in the study.

\section{References}

Adeyemo, A. (2012). Sixty per cent of Lecturers in Nigerian Universities don't have Doctorate Degreesretrieved from: http://www.bellanaija.com/2012/08/22/60percent-of-lecturers-in-nigerian-universities-dont-have-doctorate-degrees -president-goodluck-jonathan.

Aluede, O.O. (2000). Sexual harassment of women employees in a Nigerian university: Implications for counsellors. Guidance and Counselling, 15(2), 27-32.

Argus, E.R. (2004). The Social Construction of Reality Garden City, NY: Anchor. 
Berger, J., \& Milem, J. (1999). The role of student involvement and perceptions of integration in a causal model of student persistence. Research in Higher Education, 40(6), 641-664. http://dx.doi.org/10.1023/A:1018708813711

Black, P., \& Wiliam, D. (1998). Assessment and classroom learning, Assessment in Education, 5 (1) 7-74. http://dx.doi.org/10.1080/0969595980050102.

Bahou, L. (2011). Rethinking the Challenges and Possibilities of Student Voice and Agency Educate Special Issue, retrieved from: http://www.educatejournal.org/.

Blair, E., \& Noel, K.V. (2014). Improving higher education practice through student evaluation systems: is the student voice being heard? Assessment and Evaluation in Higher Education, 39(7), 879-894. http://dx.doi.org/10.1080/02602938.2013.875984.

Bloxham, S. (2007). Developing Effective Assessment in Higher Education: A Practical Guide Mainhead: Open University Press.

Bragg, S., \& Manchester, H. (2012). Pedagogies of Student Voice.Revista de Educaci'on, 359, 143-163.

Braund, M., \& Reiss, M. (2006). Towards a more authentic science curriculum: the contribution of out-of-school learning. International Journal of Science Education, 28, 1373-1388. http://dx.doi.org/10.1080/09500690500498419

Brookheart, S.M. (2001). Successful students' formative and summative uses of assessment information, Assessment and Evaluation in Higher Education, 8(2), 154-169.

Carey, P. (2013). Student engagement in university decision-making: policies, processes and the student voice. $\mathrm{PhD}$ thesis.Retrieved from: http://eprints.lancs.ac.uk/67667/

Chae, J.E., \& Hong, H.K. (2009). The expansion of higher education led by private universities in KoreaAsia Pacific Journal of Education, 29(3), 341-355.

Darling, H.L. (2012). Creating a comprehensive system for evaluating and supporting effective teaching. Stanford, CA. Stanford Center for Opportunity Policy in Education.

Evans, N.J., Forney, D.S., \& Guido, D. F. (1998). Student development in college: Theory, research, and practice. San Francisco: John Wiley and Sons, Inc.

Fredricks, J., Blumenfeld, P., \& Paris, A. (2004). School Engagement: Potential of the Concept, State of the Evidence. Review of Educational Research, 74(1), 59-109. http://dx.doi.org/10.3102/00346543074001059.

Galbraith, K. (2003). Towards quality private higher education in Central and Eastern Europe. Higher Education in Europe, 28(4), 539-558.

Gappa, J.M., \& Leslie, D.W. (1993). The Invisible Faculty. San Francisco: Jossey-Bass.

Harper, S., \& Quaye, J. (2009). Student Engagement in Higher Education. Theoretical Perspectives and Practical Approaches for Diverse Populations. New York: Routledge.

Hodkinson, P., \& Shaw, A. (2013). Timely research on Tertiary Student Voice. Retrieved from:http://exmss.org/files/2013/05/Timely-research-on-Student-Voice.pdf (accessed 27 March 2014).

Jackson, N. (2006). Creativity in Higher Education: Creating tipping points for cultural change SCEPTrE Scholarly Paper No. 3retrieved from:portal.surrey.ac.uk/...PAPER\%203\%20DEVELOPING\%20CREATIVITY.

Jalowiecki, B. (2001). Prospects for the development of private higher education in Poland. Higher Education in Europe. XXVI(3), 421-425. http://dx.doi.org/10.1080/03797720120115997.

Kuh, G.D., \& Hu, S. (2001). The Effects of Student Faculty Interaction in the 1990s. Review of Higher Education. 24 (3), 309-332. http://dx.doi.org/10.1353/rhe.2001.0005.

Kuh, G.D., Kinzie, J., Buckley, J.A., Bridges, B.K., \& Hayek, J.C. (2007). Piecing Together the Student Success Puzzle: Research, Propositions, and Recommendations. ASHE Higher Education Report, 32(5). San Francisco: Jossey-Bass.

Kuh, G., Cruce, T., Shoup, R., Kinzie, J., \& Gonyea, R. (2008). Unmasking the effects of student engagement on first-year college grades and persistence. The Journal of Higher Education, 79(5), 540-563.

Leach, M. (2012). Bursting bubbles in Higher Education. In Coiffait, L. (ed) Blue Skies: New thinking about the future of higher education - A collection of short articles by leading commentators, The Pearson Think Tank: London.

Levin, B. (2000). Putting students at the centre in education reform. Journal of Educational Change, 1(2) 155-172. 
Levy, D.C. (2007). Private public interfaces in higher education development: two sectors in sync? Paper presented at World Bank Regional Seminar on Development Economics.

Lundy, L. (2007). Voice is not enough: The implications of Article 12 of the UNCRC for Education, British Educational Research Journal, 33(6), 927-942.

Maclellen, E. (2001). Assessment for learning: the different perceptions of tutors and students. Assessment and Evaluation in Higher Education, 26(4), 307-318.

McCowan, T. (2004). The growth of private higher education in Brazil: implications for equity and quality. Journal of Education Policy, 19(4), 453-472.

McKeachie, W., \& Svinicki, M. (2006). McKeachie's Teaching Tips: Strategies, Research, and Theory for College and University Teachers (12th ed.) Boston: Houghton Mifflin.

Mhlanga, S., Matope, S., Mugwagwa, L., Phuthi, N., \& Moyo, V.S. (2013). Academic staff development strategies in engineering fields of study: case study of Zimbabwe. Proceedings of the $2^{\text {nd }}$ Biennial Conference of the South African Society for Engineering Education, Cape Town.

Oketch, M. (2009). Public-private mix in the provision of higher education in East Africa: stakeholders' perspective. Journal of Comparative and International Education, 39(1), 21-33.

Oppermann, M. (1997). Longitudinal Studies-A Methodological Clarification. Journal of Hospitality and Leisure Marketing , 4(4), 71-74.

Oppong, C. (1995). A high price to pay: For education, subsistence and a place in the job market. Health Transition Review (Supplement), 5, 35-56.

QAA (2012). Assuring and enhancing academic quality: student engagement. Retrieved from:http://www.qaa.ac.uk/Publications/InformationAndGuidance/Documents/Quality-Code-Chapter-B5.pdf (accessed 2 March 2014).

Ramsden, P. (1992). Learning to Teach in Higher Education, London: Routledge.

Reid, K. (2010). An evaluation of an internal audit on student feedback within a British university: A quality enhancement process. Quality Assurance in Education, 18(1), 47-63.

Rogers, A.L. (2005). Student Voice: Bridge to Learning retrieved from: http://depts.washington.edu/k12admin/141/capstone/docs/AndyExecSummry.DOC.

Trowler, V. (2010). Student engagement literature review retrieved from: https://www.heacademy.ac.uk/sites/default/files/StudentEngagementLiteratureReview_1.pdf.

Wilson, K., Lizzio, A., \& Ramsden, P. (1997). The Development, Validation and Application of the Course Experience Questionnaire. Studies in Higher Education, 2(1), 33-53.

\section{$(\mathrm{cc}) \mathrm{BY}$}

This work is licensed under a Creative Commons Attribution 3.0 License. 